2. Burianov, M.P. (1999). Psykholohichnyi infantylizm i suchasni problemy. Zhurnal nervopatolohii i psykhiatrii, 1, 158-199. [in Ukrainian].

3. Varha, A.Ya. (2001). Systemnaia semeinaia terapyia. Kratkyi lektsyonnyi kurs. SanktPeterburh: Rech. [in Russian].

4. Derevianykh, E.A. Sotsialnyi infantylizm v molodizhnomu seredovyshchi. Naukove tovarystvo studentiv XXI stolittia. Hromadski nauky: zb. st. po mat. XXV Mizhnar. stud. nauk.-prakt. konf., 10 (24). Retrieved from http://sibac.info/archive/social/10(24).pdf (data zvernennia: 04.11.2016) [in Ukrainian].

5. Iefremova, H.Z. (2014). Sotsialnyi infantylizm studentskoi molodi yak faktor protystoiannia suchasnomu suspilstvu. Internet zhurnal «Nauko vvedennia», 6. Retrieved from http://naukovedenie.ru/PDF/09PVN614.pdf. [in Ukrainian].

6. Iefremova, H.I. (2008). Sotsialno psykholohichni chynnyky infantylizmu v bezrobitnoi molodi, psykholohichni mekhanizmy podolannia. Kyiv: Akademvydav. [in Ukrainian].

7. Infantylyzm sotsyalnyi. Slovar praktycheskoho psykholoha. Retrieved from http://www. psdict.ru/ 15.php. [in Ukrainian].

8. Smyrnova, E.T. (2005). Ekspress-psykhodyahnostyka. Vvedenye v tselostnuiu psykholohyiu. Metodyky y testy. Samara: Yzdatelskyi dom «Bakhrakh. [in Russian].

9. Freid, A. (2010). Vvedenye v detskyi psykhoanalyz. Norma y patolohyia detskoho razvytyia. «Ia» y mekhanyzmy zashchyty: sbornyk. Mynsk: Popurry. [in Russian].

10. Shtepa, O.S. (2008). Osobystisna zrilist: monohrafiia. [in Ukrainian].

УДК 159.922.8

doi: 10.15330/psp.24.48-58

Людмила Іванцев, Наталія Іванцев

\title{
СТРАТЕГІЯ ЖИТТЯ ОСОБИСТОСТІ ТА МОЖЛИВОСТІ ÏÏ ПОБУДОВИ ЯК ПРЕДМЕТ ТЕОРЕТИКО-МЕТОДОЛОГІЧНОГО АНАЛІЗУ
}

Стаття присвячена надзвичайно актуальній і важливій проблемі - стратегії життя особистості, яка визначається як модель побудови особистістю свого життя згідно зі власними иілями, зумовленими суспільними ичілями $і$ вимогами, а також можливостями реального здійснення ичих иілей. Аналізуються основні наукові підходи до вивчення проблеми життєвих стратегій особистості у світлі сучасних досліджень. Розглядається прочес формування і трансформаиіі життєвої стратегії особистості, ї̈ основні характеристики та типологія. Означуються можсливості побудови особистістю власної жстттвої cmpameziï.

Ключові слова: стратегія життя, пасивно-адаптивний тип життєвої стратегії, активний тип життєвої стратегії, життєва програма, життєва перспектива.

The article presents the scientific research results of the life strategy concept of the individual. The possibilities of life strategy formation of the individual are discussed. The topic relevance and the need for its further, more detailed, theoretical and methodological development, taking into account the modern social context are highlighted based on scientific generalization and systematization sources.

Based on the fundamental concept, life strategy is defined as an individual's life formation model according to own goals, determined by social goals and requirements as well as the possibilities of real fulfilment of these goals.

(С) Іванцев Л., Іванцев Н., 2019.

Збірник наукових праць: психологія.

Вип. 24. С. $48-58$ 
Attention is drawn to the fact that conscious life building by the individual provides the development of an individual's life strategy, which allows the individual to gain life-building experience.

The life strategy types identification (passive-adaptive, active) are emphasized. Also, it is highlighted that the fulfilment of such life plan is accompanied by identifying and overcoming existing contradictions, conflicts, restrictions; foreseeing of person's readiness to get a lucky break timely in unexpected situations; taking into account the fact that the individual can be mistaken in initial plans as he/she may face both unexpected development opportunities and new insuperable obstacles that require plan management, and subsequently, mastering of his/her life building techniques. All this requires a lot of effort, attention, awareness, experience, wisdom and imagination stimulation.

It is noticed, that life strategy defining is not an easy matter for an individual and can't be accomplished quickly and forever. Firstly, it possesses a dynamic nature (due to issues complexity managing of which are gradual). Secondly, it is a long process due to the constant circumstances change (both internal and external).

Based on the above, it is noticed, that throughout person's life the latter should put a lot of efforts in order to carry out constant obligations; overcome different obstacles, negative situations and life problems; never rest on his/her laurels; plan his/her future life putting long-lasting efforts to carry out future goals.

Keywords: life strategy, passive-adaptive life strategy type, active life strategy type, life programme, life prospect.

\section{Постановка проблеми у загальному вигляді та її зв'язок із важливи-} ми науковими та практичними завданнями. В умовах трансформації українського суспільства пріоритетними виявляються проблеми, які пов'язані із пошуком форм і сфер самореалізації сутнісних сил індивідів, зорієнтованих на особистий вибір, особисту відповідальність стосовно свого життя, свого «майбуття». Людині як суб'єкту життя притаманна здатність до проектування своєї життєдіяльності. Винятковості людської природи таке значиме проектування набуває тоді, коли проект передбачуваного майбутнього має виразний особистісний, індивідуально-неповторний вид. Питання про те, як допомогти людині у тому, щоб вона скористалася основними моментами свого життя, зробивши свій життєвий вибір найбільш адекватним щодо своїх здібностей, можливостей і умов існування - було і залишається актуальним завжди.

Аналіз останніх досліджень і публікацій. Незважаючи на те, що термін «життєва стратегія» 3'явився в науковому обігу достатньо давно, проте існує необхідність в його подальшій теоретичній та методологічній розробці 3 урахуванням сучасного соціального контексту.

У свій час вагомий вклад у дослідження «життєвої» проблематики внесли такі дослідники як А. Адлер, Б. Г. Ананьєв, Л. І. Анциферова, А. Г. Асмолов, Е. Берн, Ш. Бюлер, Л. С. Виготський, І. Кон, Г. С. Костюк, Д. А. Леонтьєв, К. Левін, Б. Ф. Ломов, А. Маслоу, С. Л. Рубінштейн, Х. Томе, К. Роджерс, В. Франкл, Е. Фромм та інші, праці яких, утворивши певний науковий досвід, дали змогу перевести низку теоретичних моделей життєтворчого процесу у площину практики. Завдяки виокремленню нових напрямів психологічної науки проблема життєвих стратегій представлена у світлі сучасних досліджень вчених К. О. Абульханової-Славської, Г. О. Балла, М. Й. Боришевського, 
Л. Ф. Бурлачука, Є. І. Головахи, О. А. Донченко, М. Дружиніна, Ф. Зімбардо, О. О. Кроніка, К. Левіна, Н. А. Логінової, С. Д. Максименко, Ж. Нюттена, С. Л. Рубінштейна, В. О. Роменця, М. В. Савчина, Л. В. Сохань, В. О. Татенко, Т. М. Титаренко, В. Е. Чудновського, Ю. М. Швалба, С. М. Хоружого, В. М. Ямницького та інших. Науково-дослідницька увага вище згаданих фахівців спрямовується на розкриття закономірностей сприйняття та передбачення майбутнього, постановки життєвих цілей та можливостей реального здійснення цих цілей, а також на виявлення визначального впливу життєвих планів на життя особистості.

Стратегія життя у сучасному розумінні - це стратегія пошуку, обгрунтування й реалізації своєї особистості в житті шляхом співвіднесення життєвих вимог $з$ особистісною активністю, iї цінностями й способом самоствердження [15]. Свідоме творення особистістю свого життя прогнозує розробку нею власної життєвої стратегії. Даний процес передбачає високий рівень розумового розвитку, насамперед розвиток вміння мислити узагальнено, залишаючись прив'язаним до конкретних умов існування, мудрості, здатності до аналізу i рефлексії, так як, реалізація життєвого проекту супроводжується виявленням $і$ подоланням суперечностей, конфліктів й обмежень. Необхідний розвиток у цьому напрямку може бути забезпечений не тільки підвищення освіченості у різних сферах, але й спеціальними зусиллями, які стосуються оволодіння стратегічним мисленням у сфері життєтворчості.

Мета і завдання дослідження. Вивчення та аналіз фокусу основних наукових підходів до дослідження проблеми життєвих стратегій особистості, процесу формування і трансформації життєвої стратегії в контексті життя особистості, розкриття основних характеристик та підходів до типології життєвих стратегій, означення можливостей їх побудови.

Виклад основного матеріалу. Вивченню поняття життєвої стратегії як сукупності життєвих планів і програм особистості, які вона будує на основі уявлень про себе, про своє минуле і майбутнє у відповідності зі своїми життєвими планами, цілями і прогнозами присвячено низку праць багатьох представників різних наукових вітчизняних та зарубіжних шкіл. Саме психологічні, філософські, політологічні та соціологічні дослідження стали теоретико-методологічним підгрунтям у розробці поняття «життєва стратегія» в його інтерпретації. Зокрема, як принцип опори на власні сили, перетворення умов, ситуацій життя відповідно до цінностей особистості та розкриваючи його розуміння через змістові характеристики в широкому (як здатність особистості з'єднувати індивідуальні особливості, можливості і домагання з вимогами соціального середовища) і вузькому (як спосіб рішення життєвих протиріч) сенсі визначає поняття «життєва стратегія» вітчизняний науковець К. О. Абульханова-Славська; як одна зі складових елементів процесу самовизначення, який виступає елементом життєтворчості разом із життєздійсненням, осмисленням життєвих обставин та корекцією життєвого шляху розкривають поняття життєвої стратегії у контексті вивчення проблеми вчені Л. В. Сохань та І. Г. Єрмаков; як інтегральна модель побудови та здійснення особистістю власного 
життя, яка включає основні життєві принципи та цінності, життєву позицію особистості формулюють іiі І. Г. Єрмаков та Д. О. Пузіков у відповідності до розробленої теорії життєвого проектування; як структури життєвих цілей, розгорнутих у часовій перспективі психологічного майбутнього запропонували визначення життєвої стратегії дослідники М. О. Мдівані та П. Б. Кодесс; як спосіб буття, систему цінностей та цілей, реалізація яких дозволяє зробити життя найбільш ефективним життєва стратегія трактується у наукових доробках О. С. Васильєвої та Є. О. Демченко; як засіб планування особистістю власного життя, що складається 3 попереднього конструювання способу життя (вибір цілей, пріоритетів), його реалізації (практики суб’єкта, спрямовані на реалізацію життєвих потреб і розв’язання ситуацій), задоволеності життям (самооцінка досягнутого) пропонує розуміти життєву стратегію О. С. Мурадян; як засіб випереджального відображення в умовах життєвих змін розглядає життєву стратегію Ю.О. Бохонкова; як повторювану в основних сферах життєдіяльності поведінкову активність індивіда, грунтовану на моделях подолання, пристосування або уникання перешкод, що виникають у процесі досягнення поставлених цілей представляють у своїх роботах вітчизняні соціологи О. Г. Злобіна та В. О. Тихонович; як спосіб раціонального ставлення до життя, що, на відміну від інших способів (життєві цілі, життєві плани, життєві домагання, життєві цінності, життєві орієнтації), передбачає свідоме управління та планування особистістю власного життя шляхом поетапного формування майбутнього визначає у своєму соціологічному дослідженні життєвої стратегії Д. Ю. Чеботарьова; як цілісну картину майбутнього, у складному суперечливому взаємозв'язку подій, які програмуються та очікуються, 3 якими людина пов'язує соціальну цінність та індивідуальний сенс свого життя розглядає феномен життєвої перспективи Е. І. Головаха; як систему елементів, що відображають зміст майбутнього життєвого шляху, визначаючись вибором життєвої позиції (сукупність життєвих цінностей індивіда, що дозволяють так чи інакше будувати образ ідеального майбутнього) та життєвих цілей особистості (вони характеризують домінуючу сферу життя особистості та визначають ідеальний образ майбутнього життя людини) розкриває у своїх наукових дослідженнях С. І. Бабатіна; як форму або спосіб свідомого планування й конструювання людиною власного життя у відповідності з властивою їй системою цінностей, смислів і цілей характеризує життєву стратегію А. М. Ляхова тощо $[1 ; 2 ; 4-6 ; 8 ; 9 ; 11 ; 12 ; 14 ; 16 ; 18]$.

Спираючись на основні концептуальні положення розглянутих підходів ми означуємо життєву стратегію як модель побудови особистості свого життя згідно з особистісними цілями, зумовленими суспільними цілями і вимогами, а також можливостями реального здійснення цих цілей. Стратегія життя фіксує певну життєву позицію і визначає головну життєву лінію, проекцію майбутнього життєвого шляху. Відповідно, свідоме творення особистістю свого життя передбачає розробку нею власної життєвої стратегії.

Життєвий шлях особистості - це їі індивідуальна історія, яка має свої межі, певні періоди, міру завершеності і вичерпаності. Життєві події і ситуації, що 
виникають, для кожної особистості складаються у певну послідовність, яка у своїх нових якостях утворює іï життєвий шлях, формуючи при цьому індивідуально-специфічний життєвий досвід конкретної людини. Останній складається зі спогадів людини про життєві події і ситуації на основі уяви та із висновків як результату аналізу життєвих подій i ситуацій. У свою чергу, різноманіття життєвого досвіду людська свідомість прагне поєднати у відносно цілісну систему переконань та життєвих диспозицій. 3 огляду на викладене, покладаємося на точку зору К. Л. Мілютіної, яка вказує на те, що: «... система переконань та життєвих диспозицій може бути об'єднана декількома різними принципами: відкритості новому досвіду, стабілізації, само перетворенню або само підсиленню. Життєва стратегія, що побудована на системі відкритості новому досвіду, буде успішно розгортатись за умови динамічного соціального середовища, яке надає можливість отримання нового досвіду. Стратегія, спрямована на стабілізацію себе та оточення може бути максимально успішною за умов стабільного соціально-економічного оточення. Стратегія, побудована за принципами само перетворення спрямовує життєву активність індивіда не на зовнішній світ, а на суб'єктну вчинкові активність» [13].

За твердженням К. О. Абульханової-Славської, оптимальною життєвою стратегією є така, за якої людина співвідносить свої можливості з життєвими завданнями, при цьому постійно розвиваючи свій потенціал. У процесі активізації життєвої стратегї особистості постійно відбувається корекція іiі активності: індивідуум поступається соціуму у другорядних життєвих ситуаціях заради досягнення пріоритетних цілей [1].

Людське життя з погляду суб'єктивних, активно-творчих засад виступає як проблема творчого життя особистості, їі духовного світу, мети і сенсу життя. Навчитись мистецтва жити означає оволодіти вмінням будувати свій життєвий проект на основі не тільки врахування характеру часу, але й на основі самосвідомості і вміння його програмування. Процес побудови власного життя може досягати своєї кульмінації у період, коли людина має можливість здійснювати той чи інший вирішальний вибір в основних сферах своєї діяльності і самореалізації. Саме у ці моменти найбільш виразно проявляються можливості людини щодо реалізації творчого підходу до свого життя. У найзагальнішому розумінні можна виділити такі типи життєвої стратегії: по-перше, пасивноадаптивну, коли особистість є суб’єктом діяльності (праці, навчання, пізнання і спілкування), але не є суб’єктом реалізації всіх своїх внутрішніх і зовнішніх можливостей, побудови себе, коли життя в основному визначається оточенням (зовнішні і внутрішні обставини, умови, події та інші люди); по-друге, активну, коли основним принципом стає самовизначення на основі загальної світоглядної орієнтації, коли особистість бажає бути автором свого життя, брати участь у процесі його програмування з метою реалізувати свої життєві потреби у майбутньому. При цьому життєві можливості, які значною мірою визначаються зовнішніми соціально-економічними, культурно-історичними і духовно-психологічними чинниками, все ж таки не детермінують майбутнє життя повністю i однозначно, допускаючи його зміни i варіативність подальшого 
розвитку. Життя допускає майже постійні зміни і свій подальший розвиток згідно з багатьма варіантами.

Наявність життєвої стратегії i намагання дотримуватись ii дозволяє особистості набути досвіду у побудові власного життя, який полягає не тільки в тому, що особистість навчається орієнтуватись у своєму внутрішньому світі, виявляє труднощі, які потрібно подолати на шляху здійснення життєвих планів, 3'ясовує свої ресурси, нові бажання і можливі цілі, а також у тому, що вона залежить від зовнішніх умов. Життєва стратегія допомагає усвідомити, що життєві плани потрібно час від часу змінювати, пристосовуючи їх до нових обставин, що виявляються в процесі життєдіяльності, в процесі творення власного життєвого шляху. Зауважимо, що життєві плани, являючи собою часовий аспект життєвих цілей особистості, є ідеальними образами міри реалізації життєвих цілей особистості на різних віхах іiі життя у майбутньому. Апелюючи до думки I. С. Конона, відзначаємо, що становлення життєвих планів особистості відбувається тоді, коли усвідомлені не лише життєві цілі, але й способи та ресурси їх досягнення [7].

Разом 3 тим життєва стратегія не охоплює всі прояви життя. За межами запланованого відбувається гра випадкових або прогнозованих альтернативних обставин і подій, які вимагають для свого використання відповідних тактичних прийомів і методів. Однак, з іншого боку, наявність іiі дозволяє докладати систематичні зусилля, що є необхідними для розвитку у професійному або соціальному аспектах, який можливий тільки тоді, коли людина має відповідні цілі і мотиви.

У зв’язку з цим, доречними є міркування відомої у напрямку означеної проблеми вченої К. О. Абульханової-Славської про те, що кожна людина має не тільки право, а й зобов'язана, в першу чергу, перед самим собою, розумно скеровувати своє життя, зуміти привести у відповідність свої природні задатки та особистісні властивості 3 умовами життя, його можливостями та обмеженнями [1].

У форматі опису характеристик життєвої стратегії, то на особливу увагу на переконання О. С. Васильєвої та О. О. Демченко, заслуговують саме такі: рівень відповідальності, ступінь усвідомленості життя, система цінностей і відносин людини. Згідно з уявленнями згаданих фахівців, якісними характеристиками життєвої стратегії виступають життєві цілі, як риси ідеального образу майбутнього життя людини, і система цінностей, на основі якої вибудовуються визначені цілі, зауважуючи при цьому, що вони відображають зміст життєвої стратегії - те, до чого прагне людина. Кількісну характеристику життєвої стратегії наповнюють - відповідальність і осмисленість життя [5]. При цьому не менш важливим виступає той факт, що у процесі розвитку суспільства й зміни суспільної моралі людина може переосмислювати свою систему цінностей, внаслідок чого ii життєві цілі наповнюються іншим змістом [3]. Схожі ідеї отримали підтримку і в дослідженнях вітчизняних вчених Л. В. Тищенко i Ю. М. Швалба, які висловлюють своє переконання у тому, що показниками 
ефективної стратегії життя людини є іï задоволеність життям і психічне здоров'я [17].

Розглядаючи проблему формування і трансформації життєвої стратегії особистості, звертаємо увагу на пересвідчення К. Л. Мілютіної, яка вважає, що даний процес триває протягом усього життя. У своєму дослідження авторка наголошує, що іï основи закладаються ще до народження дитини, так як сімейне коло має визначені сподівання щодо можливих варіантів поведінки своєї дитини та іiі призначення в родині. Вчена переконана, що подальше формування життєвої стратегії відбувається під впливом насамперед психофізіологічних особливостей індивіда (особливості вищої нервової діяльності), що створюють фундамент для формування індивідуально-типологічних особливостей людини, зокрема акцентуацій характеру, емоційної стійкості, стратегій подолання (когнітивних, емоційних, поведінкових). Ці змінні, зауважує дослідниця К. Л. Мілютіна, складаються в життєвий стиль особистості. Піддаючи аналізу поняття «життєвий стиль особистості», в межах суб'єктно-ситуативного підходу, вона виокремлює його складові. У змістове наповнення об'єктивної складової, авторка включає індивідуально-типологічні особливості людини, які накладають свій відбиток на всі прояви іiі життєвої активності, але суттєвих змін протягом життя не зазнають. У свою чергу, суб'єктивна складова у дослідженні К. Л. Мілютіної розкривається через спрямованість особистості, яка перебуває у залежності від поєднання індивідуально-типологічних особливостей зі здатністю людини до усвідомлення та самостійної побудови системи власних мотивів і прагнень. Умови (відповідні або невідповідні) для реалізації звичного для особистості життєвого стилю утворюють зміст ситуативної складової. На думку вченої, якщо спрямованість та життєвий стиль особистості збігаються 3 можливостями їх реалізації у соціальному середовищі, то ситуація сприймається як суб'єктивно комфортна, відповідно особистість перебуває у стані адаптованості до даної життєвої ситуації. Такі умови створюють можливість для конструктивної побудови життєвої стратегї у відповідності із власною спрямованістю та можливостями [13].

Майже кожна людина здійснює вибір стосовно свого творчого ставлення до власного життя, бажання виявити себе у відповідності до своїх потенційних можливостей, пристосувати життя до себе, а не тільки самому пристосуватись до нього у відповідних точках розгалуження свого життєвого шляху. Вважається, що окремі етапи життєвого шляху відрізняються можливостями вибору у вузлових точках, тобто прийняттям особистістю рішень 3 головних, кардинальних проблем свого життя, серед яких основними є вибір навчального закладу, вибір професії, місця роботи, шляхів і темпів професійного просування, форм суспільно-політичної і культурної активності (у тому числі книжок, журналів, газет), кола спілкування (у тому числі друзів і товаришів), вибір форм використання вільного часу, самовизначення в сімейному плані тощо. 3 іншого боку, пропонується розглядати власний розвиток як процес, що вимагає прийняття аналогічних відповідних рішень у наступних видах діяльності: самоосвіта; самовиховання, тобто вдосконалення свого характеру, емоційної і мо- 
ральної сфери; вибір галузі освіти і професії; вибір місця роботи; вибір групи друзів, товаришів, колег; участь у певних організаціях; вибір пари до шлюбу і планування сім’ї; нарешті, вибір серйозних завдань на професійному рівні, а також засобів їх досягнення. Всі ці рішення стають фактом людського життя та свідомості і впливають на подальше розгортання життєвого шляху особистості, iii здатність робити правильний вибір. Проте не можна обмежитись розглядом тільки цих чинників, адже існують ще й певні причини, які кожного разу роблять вибір вдалим або невдалим, певні стратегії, які ведуть або не ведуть до успіху у названих видах діяльності.

Слід звернути увагу й на те, що якщо поняття життєвого шляху не викликає заперечень щодо його застосування до аналізу вже реалізованого життя, то застосування цього поняття до майбутнього життя людини породжує необхідність розгляду процесів проектування (планування, програмування) іiі життєвого шляху. Але проектувати життя можливо лише в цілому, тобто у вигляді певної загальної моделі, а не у вигляді плану, розписаного з точністю до послідовності конкретних подій. При цьому, з одного боку, сьогодні стає розповсюдженою думка про те, що найкращим прогноз стає в тому випадку, коли він стосується програмування майбутнього, а не є пасивним щодо можливостей його зміни у точках розгалуження життєвого шляху, у точках появи нових можливостей подальшого розвитку особистості тощо. Передбачити такі моменти можливо завдяки уточненню моделі прогнозування, завдяки кращому розумінню життєвого процесу. Саме їх використання у процесі планування або програмування життя робить прогноз все більше співпадаючим із проектом майбутнього. Однак, з іншого боку, проект майбутнього окреслити важко, передусім тому, що в міру розвитку особистості, а також суспільства, в якому вона живе, у неї з'являються нові непередбачені ситуації, а також потреби, цілі і цінності, які стають для неї більш важливими, а це може змінити ії початковий загальний життєвий план [10, с. 201].

Отже, у процесі життєвого проектування повинно враховуватись те, що може бути лише вірогідним, попереднім, допустимим тощо. Тим більш для людини все ж таки краще мати певний життєвий план, ніж не мати жодного. Вразі коли будуть виявлятись недоліки цього плану, він може удосконалюватись і ставитись у відповідність із досягнутим рівнем розуміння життя. Наявність певного життєвого плану спрощує процес проектування, надаючи особистості ту перевагу, що вона може в процесі його оновлення відштовхуватись від існуючого, вдосконалюючи його. Крім того, програмування життя, маючи динамічний характер, залежить від тих етапів і життєвих циклів, які особистість проходить упродовж життя, і які характеризуються різними рівнями іiі соціальної, психологічної та моральної зрілості. Досягнутий рівень розвитку на кожному 3 цих рівнів визначає характер цілеспрямованої діяльності, вибору життєвих цілей і засобів, корекцію життєвих планів і програм, які відбуваються щодо обраного життєвого кредо, життєвого призначення та життєвої перспективи, життєвого замислу. У процесі програмування життя корисним може виявитись також поняття життєвої перспективи, яка відповідає 
потенційній можливості у розвитку особистості, можливим або неминучим змінам у майбутньому, а також поняття життєвих намірів, які виникають на основі життєвих перспектив. Розмиті і швидше емоційні, ніж конкретнологічні, життєві наміри служать основою для пошуку життєвих перспектив, яких може бути декілька, тим часом як життєвий план можливий тільки один. Це поняття може бути корисним, наприклад, тоді, коли людина має життєві перспективи, які запропоновані їй середовищем, але, крім того, вона може мати ще й свої життєві наміри, які не збігаються з ними.

Особистість може також мати не зовсім усвідомлені наміри, які відповідають іï прихованому потенціалу, які вона ще не усвідомила до кінця, але невгамовані, хоч і неусвідомлені. Почуття часом дають про себе знати, виликаючи невдоволення і навіть депресію. Отже, не слід виключати 3 аналізу й того тиску на особистість, який визначається вихованням, освітою, оточенням i засобами масової інформації. Життєвий задум майже завжди не є чимось остаточно встановленим і чітко вираженим. Він практично ніколи не тільки не відомий остаточно, але й не усвідомлюється до кінця. Натомість людина може мати лише певні бажання або мотиви, які дозволяють ій певною мірою орієнтуватись в наданих можливих варіантах свого подальшого розвитку, особливо тоді, коли щось настає зненацька і людина до цього не готова. Крім того, людина має мрії, які передують більш конкретним життєвим планам i задумам. Тому життєві плани і сценарії повинні постійно уточнюватись і вдосконалюватись під впливом цих нечітких бажань і мотивів. Ці бажання можуть виникати як внаслідок довготривалого виховання, так і спонтанно під впливом спілкування 3 найближчим оточенням, а також під впливом культурних традицій, літературних творів, а останнім часом у багатьох випадках слід брати до уваги впливи засобів масової інформації, які, до того ж, можуть бути неусвідомлюваними [10, с. 202].

У реальному житті особистість повинна також приділяти увагу одночасно i регулярним обов'язкам та перешкодам, і різноманітним кризам, і проблемним ситуаціям, які становлять неминучий фон, на якому відбувається життя. Серед технік і прийомів програмування власного життя слід виділити такі, що стосуються: по-перше, умов, які визначаються регулярними і довготерміновими життєвими перешкодами, для подолання яких людина повинна докладати зусилля, і регулярними обов'язками, які вона повинна виконувати, щоб пристосуватися до життя. До таких життєвих перешкод слід також віднести різноманітні спокуси, серед яких варто виділити спокусу людини жити одним днем, не переймаючись довгостроковими цілями; по-друге, це випадкові або нерегулярні проблемні, ситуації, конфлікти і кризи, які іноді дуже загострюють становище людини і роблять необхідність свого розв’язання дуже бажаним для неї.

Висновки та перспективи подальших досліджень. Таким чином, впродовж свого життя людина повинна докладати регулярних зусиль для того, щоб виконувати певні регулярні обов'язки; долати всілякі перешкоди та несприятливі ситуації; не заспокоюватись на цьому, ставати над звичайним життям, над поточними справами і планувати своє подальше життя, докладаючи певних, 
частіше довготривалих, зусиль для виконання відповідних планів. Визначення i своїх життєвих перспектив, i життєвих намірів, i програмування життєвого шляху не є простою справою, яку можна швидко завершити раз і назавжди. Вони мають динамічний характер: по-перше, внаслідок складності питань, вирішення яких визріває поступово іє довготривалим процесом, а, по-друге, внаслідок постійної зміни обставин, зовнішніх і внутрішніх, впродовж усього життя. Зважаючи на це, проектування життєвого шляху вимагає від особистості значних зусиль, уваги, обізнаності, досвідченості, певної мудрості і напруги фантазії. А тому залишається актуальною необхідність у конкретних техніках, які могли б навчати людину знаходити і творити власні стратегії життя, вчили мріяти, конструювати плани свого життя, конкретизуючи ці мрії, і могли б допомагати з'ясовувати можливий сенс свого життя, що і виступає перспективою наших подальших розвідок.

1. Абульханова-Славская К. А. Стратегия жизни. Москва : Мысль, 1991. Т. 5. 297 с.

2. Бабатіна С. І. Особливості формування життєвої стратегії в юнацькому віці : теоретичний аналіз питання. Науковий вісник Херсонського державного університету. Серія : Психологічні науки. Херсон, 2015. Вип. 2 Т. 1. С. 120-126.

3. Бекасов О. Б. Анализ событийной структуры жизненного пути личности. Гуманистические проблемы психологической теории. Москва, 1995. С. 169-179.

4. Бохонкова Ю. О. Психологічні основи випереджальної стратегії поведінки особистості. Луганськ : Ноулидж, 2012. 405 с.

5. Васильева О. С., Демченко Е. А. Изучение основных характеристик жизненной стратегии человека. Вопросы психологии. 2002. № 4. С. 74-85.

6. Головаха Е. И. Жизненная перспектива и профессиональное самоопределение молодежи. Киев : Наукова думка, 1988. 144 с.

7. Гринева О. М. Специфика жизненных целей и планов личности в позднем юношеском возрасте. Вестник Актюбинского регионального государственного университета имени К. Жубанова. Педагогика и психология. Актюбинск : АРГУ им. К. Жубанова, 2017. № 4. C. 225-235.

8. Злобіна О., Тихонович В. Суспільна криза і життєві стратегії особистості. Київ : Стилос, 2001. $237 \mathrm{c}$.

9. Єрмаков І. Г., Пузіков Д. О. Життєвий проект особистості: від теорії до практики. Практико-зорієнтований посібник. Київ : Освіта України, 2007. 212 с.

10. Іванцев Л. І., Іванцев Н. І. Ціннісний вимір життєтворчості майбутнього фахівця : монографія. Івано-Франківськ : Тіповіт. 2008. С. 198-204.

11. Ляхова А. Психологические составляющие жизненной стратеги. Вестник КемГУ. 2010. № 3 (43). C. 83-90.

12. Мдивани М. О., Кодесс П. Б. Методика исследования жизненных стратегий личности. Вопросы психологии. 2006. № 4. С. 146-150.

13. Мілютіна К. О. Психології зміни життєвої стратегії особистості : дис. ... докт. психол. наук. Київ, 2013. 430 с.

14. Мурадян О. С. Життєві стратегії особистості в умовах соціальних змін: соціологічний аналіз. Соціологічні студіï. Луцьк : Східноєвроп. нац. ун-т ім. Лесі Українки, 2013. № 1 (2). C. $49-54$.

15. Резник Ю. М., Смирнов Е. А. Жизненные стратегии личности (опыт комплексного анализа). Москва : Институт человека РАН, Независимый ин-т гражданского об-ва, 2002. $260 \mathrm{c}$. 
16. Сохань Л., Срмаков І. Життєва компетентність у технології життєздійснення. Кроки до компетентності та інтеграції в суспільство : наук.- метод. зб. Київ : Контекст, 2000. $336 \mathrm{c}$.

17. Швалб Ю. М., Тищенко Л. В. Майбутнє і сьогодення студентів з обмеженими функціональними можливостями: психологічні аспекти. Київ : Основа, 2015. 239 с.

18. Чеботарева Д. Ю. Жизненные стратегии студенческой молодежи юга России : автореф. дис. ... канд. социол. наук. Ростов-на-Дону, 2006. 26 с.

\section{References}

1. Abulkhanova-Slavskaya, K.A. (1991). Life strategy. Moscow: Thought. [in Russian].

2. Babatina, S.I. (2015). Features of life strategy formation in adolescence: theoretical analysis of the issue. Scientific Bulletin of Kherson State University. Series: Psychological Sciences, 2 (1), 120-126. [in Ukrainian].

3. Bekasov, O.B. (1995). Analysis of the event structure of the life path of the individual. Humanistic problems of psychological theory. Moscow. [in Russian].

4. Bohonkova, Y.A. (2012). Psychological bases of the leading strategy of personality behavior. Lugansk: Knowledge. [in Ukrainian].

5. Vasilyeva, O.S., Demchenko, E.A. (2002). The study of basic characteristics of human life strategy. Psychology issues, 4, 74-85. [in Russian].

6. Golovakha, E.I. (1988). Life prospect and professional self-determination of youth. Kyiv: Scientific Thought. [in Ukrainian].

7. Grineva, O.M. (2017). Specificity of life goals and plans of a person in late adolescence. Bulletin of Aktobe Regional State University named after K. Zhubanov. Pedagogy and psychology, 4, 225-235. [in Russian].

8. Zlobina, O., Tikhonovich, V. (2001). Social crisis and life strategies of the individual. Kyiv: Stylos. [in Ukrainian].

9. Yermakov, I.G., Puzikov, D.A. (2007). Life project of personality: from theory to practice. Practically oriented guide. Kyiv: Education of Ukraine. [in Ukrainian].

10. Ivantsev, L.I., Ivantsev, N.I. (2008). Tsinnisniy vymir tvorchoho potentsialu maibutnoho zhyttia [Valuable measurement of the future specialist's life]. Ivano-Frankivsk: Tipovit. [in Ukrainian].

11. Lyakhova, A. (2010). Psychological components of the life strategist. Visnyk of KemSU, 3 (43), 83-90. ( [in Russian].

12. Mdivani, M.O., Kodess, P.B. (2006). Methods of study of life strategies of the individual. Psychology issues, 4, 146-150. [in Russian].

13. Milutina, K.O. (2013). Psychologies of change of life strategy of the person. Doctor's psych. Kyiv. [in Ukrainian].

14. Muradyan, O.S. (2013). Life strategies of personality in conditions of social change: a sociological analysis. Sociological studies? 1 (2), 49-54. Lutsk: Eastern Europe. nat. them. Lesia Ukrainka. [in Ukrainian].

15. Reznik, Yu.M., Smirnov, E.A. (2002). Life strategies of the individual (experience of complex analysis). Moscow: Institute of Human Sciences, Russian Academy of Sciences, Independent Institute of Civil Oblast. [in Russian].

16. Sohan, L., Yermakov, I. (2000). Vital competence in the technology of life realization. Steps to competence and integration into society: a scientific method. sat. Kyiv: Context. [in Ukrainian].

17. Schwalb, Yu.M., Tishchenko, L.V. (2015). The Future and Present of Students with Disabilities: Psychological Aspects. Kyiv: The Basis. [in Ukrainian].

18. Chebotareva, D.Y. (2006). Life strategies of student youth of the south of Russia. Extended abstract of candidatr's thesis. Rostov-on-Don. [in Russian]. 